\title{
A Diary of Women: I Meet Anita Ekberg
}

I was watching her come down the street. "Here comes my fate after me," I said. I didn't know her. Never seen her before. She was a statuesque blonde.

Stepping out on the street to block this woman's way I realized I was acting at the behest of my overweening imagination again. My feverish brain, alerted, began its frenzied back tracking, casting about for a way out. Anything to put a good face on it.

"Are you Anita Ekberg?" I asked. That was the dodge. Mistaken identity.

"Yes," she said and smiled at me, waiting to give me her autograph as soon as I produced my book and pen. I had neither.

"I've seen your movies," I said.

"How nice."

"Where are you going now?"

She shook her head, half smiling. "I'm not giving interviews."

"You're not giving interviews? But what am I to do?"

She smiled with charm and finality and began walking away. My ruse had worked. My fertile brain, always on call for the stupid blunders of the personality it served, had bailed me out again, coming to my rescue for the I don't know how manyth time until I accepted it as an ordinary course of events. I was saved again.

I returned her smile, bowed out, stepped aside and mentally wiped my brow, breathed a sigh of relief, as it were, mixed with my brain's sputter of disgust.

But don't you know, I wasn't off so easy. She hadn't taken two steps when, motivated by who knows what relenting nature or cupidity for publicity, Miss Ekberg stopped in her tracks and looked back over her shoulder at me. She commanded me with a signal jerk of her head to come along with her. I was still on the hook. I had a notion to confess all, but I knew that would never do. They might lock me up. For all my wailing about there not being enough facilities for people like me, privately I was just as glad there weren't. I liked being at liberty, living side by side with, almost indistinguishable from, the norm.

I fell into step with her. She began talking rapidly about her assignment here and what it meant to her and to her career and things like that. Then she started filling me in on background information that you could get from any press agent's dope sheet.

"No. No," I said, falling into the role easily and comfortably. I knew there was no escape now. I began to look at it with more faith, ignoring these shuddering reminders that I was slipping once more across the line. 
"I want something extra. I want what you don't tell your public."

"So you can tell them for me?"

"No. No. You don't understand. It's only to give me a private understanding of you. That's how I get depth into my stories."

"I see."

"What I need are details of your personal life, Anita. Intimate details. The nakeder you show yourself to me the better dressed I can show you to your public."

"I'd like to see tear sheets of these interviews."

I suspected she doubted my word. "Yes," I said abruptly. "We have reached a standstill, haven't we? I'll send my scrapbook round." I prepared to depart.

She caught my elbow, leaning on it, leaning toward me as I had seen her do to the male lead in how many movies? "That won't be necessary. Come along with me and I'll tell you what you want."

We arrived at her hotel. She took a number of message slips from the clerk and put them unread in her handbag, walked through the crowded lobby nodding and smiling, murmuring apologies to some, but didn't stop.

Me, I was walking in a dream and didn't wake up until I was in her room. But I felt the residue of recent pressure on my arm indicating I had been guided by her strong Scandinavian fingers. The door closed and the hubbub ceased and I realized where I was. The darling captress had kidnaped me.

Immediately she disappeared. I was left alone for almost fifteen minutes while she changed. I heard the shower. When she came out her hair was down and she was wearing no makeup. No girdle, no bra; I guessed that much. She settled herself in a chair, picked up the phone for room service and, unsmiling, asked if she could order something for me, pointed to a bottle and told me to help myself.

A lot of her accent had disappeared. "I'm about to tell you things I haven't even confessed to myself," she said. "Can you take it?" She poured from the bottle.

I nodded seriously, gulping, hamming it. I knew she was lying. I knew she was not about to tell me anything like that. I was not even sure she was in the room. Reality and dream had diverged and I was following the dream.

"What you are about to hear-" she began dramatically, from what old movie I couldn't remember. She gave me a broad wink.

Room service knocked. I went to the door and gave entry to the waiter and his assistant. I tipped the old waiter liberally as might be expected of the consort of a lady of such generous endowment.

We sat down to the little repast in the best of spirits and as soon as her 
mouth was full she began to talk rapidly in a different manner than she had previously. I thought her accent might disappear but it became thicker, heavier, until I couldn't even understand her.

It was a Swedish girl I was listening to. She was just entering her teens, about to become a woman, a dreamy, unhappy, brooding girl who sat by the fire and listened to the adult talk around her and made up impossible fantasies about her future life as a great movie star, greater than Greta Garbo, greater than Ingrid Bergman!

I couldn't interrupt to tell her to talk English and so I missed most of what she said. But I got the tone of it, the passion, the human quality.

It was dark when she let me out with a weary smile, kissed me affectionately and closed the door on me. I stood in the hall and was free.

It was really the desire to prolong the aura of her presence, I suppose, that led me to the press room of the hotel where I wrote out all I could remember. I marked my copy for the Sunday Section and took a taxi to the newspaper and dropped it off.

The paper sent a Kodak boy to get close-ups. They gave the story a big play. Anita has just called and told me she wants to see me so she can thank me.

\section{Women Without Qualities: Chapter IV}

We came to Naples as we come to life.

"Some men build boats," my sister said one day. How like her.

"Some women go to Naples," I said.

"Why do they, Bunny?"

"They think it's the thing to do."

"Is that so?"

"They don't argue."

"Why don't they argue?"

"They see that argument is useless."

"I wonder."

We left the chateau on a drizzly November day. Naples was sunny. You might expect it.

"The world is our oyster," I said. "I needn't tell you that." She gave me a pretty smile then.

It began to snow in the mountains around us. We woke up in the morning and looked out on a beautiful bay and we were lonely. We were not often lonely. We had tired of looking for husbands. 